\title{
コンピューター導入について
}

清酒製造業の経営戦略化構造改善計画の主なものの一つとして，コンビュータリゼイション事業があげられて いる。各個別企業の O A 化も進行している時, 業界として総合的な情報処理システムの検討が急がれる。

\section{吉田壽 男}

今般第四次清酒製造業の構造改善事鄴が実施されるこ とになり，この計画に沿った事業の一つとしてコンピニ 一ターを各企業に導入し，これを利用した情報処理につ いて話をすすめる。

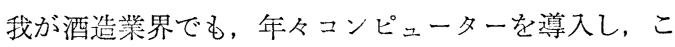
れをフルに活用し成果をあげている企筆も多いことであ ろらし，その反面まだ利用されていない企業の力々も多 いことと思う。

この両者を含めて, 清酒製造業の体質改善を計るたら に、コンピューターを導入し，相互利用を計ってはと思 い提案する。

申すまでもなく，酒造業界は酒税を加算した酒を販売 している関係上, この酒税保全のため監督官庁によって 記帳が義務づけられ, 様式が統一されている検査簿と, これに付随した申告書類がある。

また経理面に招いては，中央会の小牧先生が指導作成 された，財務諸表並びに諸表樣式があるので，経理諸蛝 簿の様式を統一することも容易にできると思う。このよ らに清酒製造業の全業者が同一様式にすべて統一し利用 できるということは, コンピューター化には打ってつけ の業種であり，全業者が同一のもの公利用できるという ことで経費も安くすむことになる。

もし各企業がュンピューターを導入したとすると， こ れぞれの企業の事務処理の能率化経営管理, 市場管理,

財務管理が効率よく運営ができ, これを利用して自己の 財務体質の改善が可能になる。

さらに中央会各支部各県酒造組合にも設置したとすれ ば, 各企業のコンピューターと通常の電話回線を利用し て接続し，それぞれ 相互に情報文書の 交換が 1 秒間に 210 文字の速さで, 郵便料金より安く正確に交換でさる ことになる。

またこの交換した情報資料をニンピューターに記憶さ せ蓄積しておくと，データーバンクとして 企業別，級 別，地域別，月別，年別の集計とか，これらの何力年分 対比表とか，人手ではとても長時間を必要とする作業も
短時間の内に処理ができ，このデーター穵タイブライタ 一で打ら出して一覧表として見ることもできる。

次にコンピューター利用について具体的に記す。コン ピューター利用に対する篗者の考兵は，冒頭でも述べた ように，個々の企業はそれぞれの業務に合ったニンピニ 一ターを設置利用し，この各企業のコンピューターを霓 話回線を利用して罧酒造組合，各支部が中央会のコンピ ューターに連結して情報資料の収集伝達文書の交換のス ピード化，正確化に役立てることが目的である。各企業 がコンピューターを導入して，それぞれができる業務之 しては得意先別売上，売掛金管理，商品资材管理，各檢 査簿, 課税申告書の作成, 文書の作成, 酒造組合への資 料報告書の作成，これらの送受信等酒避メーカーとして 必要な記帳作丵，書類作成は総べて処理が可能となる。 また中央会，各支部，各紧酒造組合でできる籍務として は資料の収集統計業務，データーバンク菜務，文臯の作 成とこれらの配信業務がある。

さらにセンターシステム化されたニンピューターを覚 大したとすれば，各企箖が設置したコンピニーターの能 力を越えた部分の事務処理計算, 資料の集計作柴ができ ることになる。このことは各企業では，年間の最多忙期 である10 月から 12 月に合せた機種を選定するのでる なく, 自己の平均的売上げに合ったニンピニーターを薄 入すれば良いことになる。

次にコンピューター導入の費用について記す。

まず最初に述べておきたいことは、コンピューターは 万能の機械ではなく，筫入設置したからすぐにどんな仕 事でもするし，人件费の筑約になり経費も安くすむとい らものでもない。气しろコンピューターを潁入なればを の分だけ経費がかかると考えていただきたいと思う。た だ，経費をかけた以上の利益をどのよらにして得るかと いうことは，それぞれて企業が如何に効率良くコンピュ 一ターを利用し，出てくるデーターを最大限に活用して 売り上げの増加を計り，経費の削減につなげるかという ことになると思う。 
先程から述べているようにコンピューターは万能な機 械ではなく，人間の指示命令によってのみ可動し、コン ピニーター自身では何もできない機械ある。

そこで人間がコンピューターに仕事の内容, 手順を如 何に正確に適切に指示してやるかによって同じ機種でも 能力が違ってくるし, 将来コンピューターの運転費用に 当影響することになる。このコンピューターに指示命令 サる手順をプログラムという。

このようにプログラムはコンピューター運転にとって 沙大切なものであり，また財産となるものであるから業 務内容に合った完全なるのを開発する必要がある。

このためにはどらしても機械に精通したプロの人達の カと,すでにコンピューター资導入して活用されている 企業の方々のご協力も得なければならないと思う。

このプログラム開発が一番費用も要するし，日時もか かることになる。この費用が扮怙よと 1 千万円位必要で はないかと思らが，この費用は，このプログラムを利用 送する企業の方々の負担とすると，利用する企業が多け れば多いほど，分割され安くなる。

次にコンピューター本体の費用について述べる。コン ピューターはキーボードの付いた本体と白黒またはカラ 一のデスプレー，資料を打ち出すプリンターとこれを電 琴する装置から檄成されている。

コンピューターは夫々の企業の事務処理量によって能 力の異なる機種を選定しなければならないので, 確定し た費用を記すことはできないが，一応目安すとして述へ ると, 大体年間売上 $400 \mathrm{kl}, 2,000$ 石位の企業で 5 力年 間, リース毎月の保守料を含んで月額 4 万円位, $2,000 \mathrm{k} l$ 1 万石位の企業で 7 万 5 千円位の費用になると思う。

中央会, 各支部, 各県酒造組合の場合センターシステム 化された機種を導入すれば月額 41 万円位のリース料と なる。この機種にはメールボックスが組込まれている。 このメールボックスは文書資料の配布先 128 カ所を記憶 して沶り，配布したい情報資料をコンピューターに入れ ることにより自動的に指示した配布先に遂次送信する。
この外の費用として用紙代と情報を記録して拧くフロッ ピイーデスクが必要である。

これ等は全企業が同一のものとするのでかなり安いも のになる。

一応この費用として用紙代が月額 5,000 円位, フロッ ピィデスクは 50 枚用意するとして 9 万円位であるが, これは 2 カ年使用できるので, 月割にすれば 3,750 円と なる。この外に若干の費用がかかる。

以上述べたようにプログラムの開発費用を始めとして 経費のかかることではあるが、コンピューターがする仕 事の内容からすれば決っして高いものではなく, 利用す る効果の方がはるか沉高いと思う。

またコンピューターの操作はそう面倒なるのではな く, 大体 3,4 日の講習を受汀れば十分対応できるまで修 得できる。もし, 中央会の事業としてコンピューターを 利用した全国ネットワークの情報処理システムを取り上 げる考觉であれば，まず早急にコンピューターメーカー の選定を急いでいただきたいと思う。というのはコンピ ニーター導入を計画している企業があり，それぞれ異っ たメーカーの機種を選定しているとすると, 情報処理の 目的であるコンピューター同志の連結が困難になる。

その上，一番費用のかかるプログラム開発費用をその 企業が単独で負担することになるから, 特定な作業だけ のコンピューター利用のプログラムだけの開発に終ると 思う。

これまで述べたことで抢判りいただいたと思らが、コ ンピューターを導入して, 各企業の仕事は各企業でそれ ぞれ処理し, 事務処理の合理化, 改善を計り, さらにコ ンピューター同志を中央会まで逐次連結することによっ て情報資料, 文書の交換が正確に迅速にできるというこ とを述べたかった訳である。

今日の情報化時代に対応したシステムとして是非中央 会等で早急に決断されることを希望する。

(二北酒造(株)) 